\title{
Empowering women through water hyacinth enterprise- An impact analysis
}

\author{
RUPJYOTI BHATTACHARJEE, HEMANJALI HAZARIKA AND PABITRA KR. BORDOLOI
}

Received: 21.04.2015; Revised: 27.10.2015; Accepted: 05.11.2015

See end of the paper for authors' affiliations RUPJYOTI BHATTACHARJEE Krishi Vigyan Kendra (A.A.U.), DARRANG (ASSAM) INDIA Email : rupjyotibhattacharjya@ gmail.com
DABSTACT : Water hyacinth (Eichhornia crassipes), known as Pani meteka in assamese, is a free-floating aquatic weed found in almost every state including Assam with vast water bodies where in it causes havoc especially in the fisheries, choke lakes and provide a breeding ground for mosquitoes. However, the stem of water hyacinth can be used as the raw material for making the most important value added products like ladies hand bags, purse, mobile covers, file covers, hand fans etc. This can not only boost up the handicraft sector and the artisans but also create employment avenues and can also fetch good foreign exchange. In this context, a study was attempted to examine the participation of rural women in water hyacinth enterprises for uplifting the economic status of their families with special reference to the Darrang district of Assam. Two nos of localities namely- Hussain chuburi and Duni from Pachim Mangaldai development block has been purposively selected on the basis of the training, demonstrations and exhibition conducted by Krishi Vigyan Kendra, Darrang for the year 2011-12, 2012-13 and 2013-14. The primary data were collected through questionnaires filled up through personal interview. It was observed that the number of rural women engaged as small entrepreneurs in water hyacinth enterprises after training and demonstration was 9 and 8 in locality- 1 and 2, respectively. It can be concluded that 24 per cent, and 27 per cent of income were shared from water hyacinth enterprises into the family's total income from all the sources in locality 1 and locality-2, respectively.

KEY WORDS: Water hyacinth, Training, Demonstration, Small entrepreneurs, Income generating activities

- HOW TO CITE THIS PAPER : Bhattacharjee, Rupjyoti, Hazarika, Hemanjali and Bordoloi, Pabitra Kr. (2015). Empowering women through water hyacinth enterprise-An impact analysis. Asian J. Home Sci., 10 (2) : 364-370. 